\title{
Leptin Deficiency
}

National Cancer Institute

\section{Source}

National Cancer Institute. Leptin Deficiency. NCI Thesaurus. Code C120384.

Deficiency of the adipose tissue-derived peptide hormone leptin, associated with loss-offunction mutation(s) in the LEP gene. 